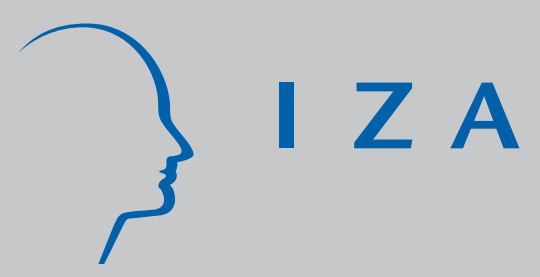

IZADP No. 2813

Self-Employment and Parenthood:

Exploring the Impact of Partners, Children and Gender

Ruta Aidis

Cecile Wetzels

May 2007 


\title{
Self-Employment and Parenthood: Exploring the Impact of Partners, Children and Gender
}

\author{
Ruta Aidis \\ University College London \\ and FEE, University of Amsterdam \\ Cecile Wetzels \\ FEE, University of Amsterdam \\ and IZA \\ Discussion Paper No. 2813 \\ May 2007
}

IZA

P.O. Box 7240

53072 Bonn

Germany

Phone: +49-228-3894-0

Fax: +49-228-3894-180

E-mail: iza@iza.org

\begin{abstract}
Any opinions expressed here are those of the author(s) and not those of the institute. Research disseminated by IZA may include views on policy, but the institute itself takes no institutional policy positions.

The Institute for the Study of Labor (IZA) in Bonn is a local and virtual international research center and a place of communication between science, politics and business. IZA is an independent nonprofit company supported by Deutsche Post World Net. The center is associated with the University of Bonn and offers a stimulating research environment through its research networks, research support, and visitors and doctoral programs. IZA engages in (i) original and internationally competitive research in all fields of labor economics, (ii) development of policy concepts, and (iii) dissemination of research results and concepts to the interested public.
\end{abstract}

IZA Discussion Papers often represent preliminary work and are circulated to encourage discussion. Citation of such a paper should account for its provisional character. A revised version may be available directly from the author. 


\section{ABSTRACT \\ Self-Employment and Parenthood: Exploring the Impact of Partners, Children and Gender}

This paper explores the relationship between self-employment, partner's employment, the household and children on a mother's and father's probability to choose self-employment. Few studies are available on this topic and their analysis is mainly limited to the female role in the North American context. In this study, we examine the influence of personal characteristics, household and labor market characteristics for both mothers and fathers in a family context and their probability to be self-employed as compared to parents who have chosen formal, gainful employment. We focus on the data from the European context comparing results from Spain, Italy and the Netherlands. Using these large and comparable data sets, our logit model estimates show that mothers who choose self-employment do not work fewer working hours than those in gainful employment. Similar results were found for fathers in Spain and Italy. Perhaps the most striking result is the very strong significance of the partner's self-employed status on the choice for self-employment for both mothers and fathers in all three countries. Other effects such as human capital, household income, presence of grandmothers and number of young children indicate country differences.

JEL Classification: $\quad$ M13, J24, J13, J16

Keywords: entrepreneurship, parenthood, self-employment, gender, Europe

Corresponding author:

Cecile Wetzels

Faculty of Economics and Econometrics

University of Amsterdam

Roetersstraat 11

1018 WB Amsterdam

The Netherlands

E-mail: cwetzels@fee.uva.nl 


\section{Introduction}

The decreasing rates of fertility in many European countries (especially in southern European countries such as Italy and Spain), has sparked concern as to the factors that contribute and or inhibit women from having children. At the same time, European countries have recognized the importance of entrepreneurship as the 'engine for economic growth' through its innovative capacities and potential to create new jobs. In this paper we explore how these two issues may be related by examining the impact of parenthood on the choice of self-employment in three European countries. Though studies focusing on female entrepreneurs have indicated that self-employment may be easier to combine with family responsibilities, (Goffee and Scase, 1983; Scott, 1986; Kaplin, 1988; Buttner, 1993; DeMartino and Barbato, 2003), little actual empirical work has been carried out in this area in the European context. By utilizing data collected by Eurostat on households in the Netherlands, Italy and Spain, we investigate this relationship using regression estimation techniques. The existing literature identifies entrepreneurship in many different ways. In this paper, entrepreneurship is proxied by self-employment. 'Families' are defined as two partners ${ }^{i}$ (either married or cohabitating) with 'children living in the household' and as such highlighting the family's care-taking dimension.

There is no study known to us that has analyzed the choice for self-employment as compared to paid employment in the labor market across European countries. This study aims at filling this gap by analyzing three countries where childcare is not widely available in the period when children are under 3 yrs. and therefore the risk of not being employed or to seek for alternatives such as self-employment may be more likely than in other countries.

The main contribution of this paper is to further broaden the analysis of family effects such as household composition, partner's employment status and the parental roles of mothers and fathers on the choice for self-employment. Some comparable yet limited studies exist based on North American data (see Caputo and Dolinsky, 1998; Connelly, 1992). However, to date little research on these issues has been conducted in the European context. Though it would be possible for us to focus on one European country and extrapolate generalizations from these results, given the vast differences between European countries in terms of cultural values as well as social policies toward employment and childcare, we include three countries (Spain, Italy and the Netherlands).

This paper is structured as follows. Section two presents an overview of relevant literature on research and results focusing on female entrepreneurs and the balancing of family and work obligations. Informed by the findings of existing studies, we develop our hypotheses in section three. Section four discusses the data and methodology used. Our empirical results are presented and discussed in section five. The paper ends with a conclusion in section six.

\section{Literature Review}

In this section's first part, we present some of the main findings regarding differences between male and female entrepreneurs ${ }^{\mathrm{ii}}$ found in the literature. In this section's second part, we provide some background information regarding differences in 
the European context focusing on labor force participation rates, labor regulations and childcare policies.

\subsection{Gender, children and family as it relates to entrepreneurial activity}

A number of studies have indicated that differences do exist between male and female SME owners in OECD countries (Goffee and Scase, 1985; Carter and Cannon, 1992; OECD, 2000a; OECD, 2000b). In terms of business performance as measured by business size (employees) or business turnover, a number of studies have indicated that female businesses tend to be smaller than male-owned businesses and have a lower business turnover (Schwartz, 1976; Charboneau, 1981; Humphreys and McClung, 1981; Welsch and Young, 1982; Goffee and Scase, 1983; Hisrich and Brush, 1987; Chaganti, 1986; Longstreth et al., 1988; Smith et al., 1982; Cuba et al., 1983; Scott, 1986; Neider, 1987; Du Rietz and Henrekson, 2000). Also, female-owned businesses have been found to grow at a slower rate than male-owned businesses (Kalleberg and Leicht, 1991: Singh et al. 2001).

In terms of financial performance, earlier studies have indicated that male business owners are more successful than female business owners (Cuba et al., 1983; Aldrich, 1989). Though few comparative studies exist, more recent studies indicate that female-owned businesses do not perform differently than male-owned businesses in terms of employment, growth, survival or profitability (Kalleberg and Leicht, 1991; Johnson and Storey, 1993; Cooper et. al, 1994; NFWBO, 1996). It should be noted that these studies were country specific and in some cases, such as the study by Kalleberg and Leicht (1991), the data was limited to only three industry sectors in one region of the US.

The differences between the financial performance of male and female-owned businesses suggest that profit and growth may not be the main goal of female-owned businesses (Brush, 1992:14; Van Uxem and Bais, 1996). For example, a qualitative study conducted by Carter and Cannon (1992) in the United Kingdom suggests that female entrepreneurs tend to run their businesses so that the interests of their businesses do not conflict with the interests of the immediate family. Fasci and Valdez (1998) further argue that one of the reasons why female businesses tend to be smaller and less profitable is precisely because these women have chosen to go into business so that they can also focus on their family needs.

Research has indicated that women often become entrepreneurs in order to balance work and family, while more men become entrepreneurs for wealth creation and economic advancement (Goffee and Scase, 1983; Scott, 1986; Kaplin, 1988; Buttner, 1993; DeMartino and Barbato, 2003). The De Martino and Barbato study (2003) conducted amongst 261 MBA graduates in the US, found that married female entrepreneurs with dependent children were most significantly motivated to go into business to balance family and business responsibilities. This was found not to be the case for married male entrepreneurs with dependent children. Moreover, Still and Timms (2000) show that family considerations are especially important for female entrepreneurs that do not have to rely on their businesses as the primary source of family income.

In addition, researchers have indicated that specifically for mothers, entrepreneurship affords greater flexibility necessary for managing domestic and employment responsibilities (Darian, 1975; Scott, 1986; Birley, 1989; Brash, 1992, 1990). Additional studies have also found support for the claim that in the US, the presence of 
small children influences a mother's choice for self-employment (MacPherson, 1988; Connelly, 1992; Robinson and Sexton, 1994). Caputo and Dolinsky (1998) found that the presence of young children in the household significantly increase the likelihood of a woman to be self-employed.

However, the life-span approach, as put forward by Cohen (1996) stresses that the entrance of women into self-employment is in most cases, delayed until the children are adults or may in some cases be completely hindered due to the presence of children. On a similar note, in a study of 220 female entrepreneurs in Israel, the age of the entrepreneur's children was associated with profitability (Lerner et al., 1997: 333). The results seem to suggest, that women with older children have more time to devote to making their businesses successful, whereas women with younger children are more focused on meeting their family responsibilities.

Using European Community Household Panel (ECHP) data from 1994 - 1998 for eleven Western European countries ${ }^{\text {iii }}$, Hildebrand and Williams (2003) find that the number of children in the household is positively related to self-employment at least amongst women. Their results also indicate that in many European nations, selfemployed women on average spend less time 'looking after their children'. However, since the definition for 'looking after' is not the same as 'caring for' these results are somewhat ambiguous in terms of their implications for self-employment and childcare.

In addition, studies have also indicated that there are barriers to self-employment for women. Patriarchal pressure in society may hinder women from entering selfemployment, though the evidence is mixed and often contradictory (Brush, 1992; Marlow, 1997; Carter and Rosa, 1998). Another possible obstacle for females to enter selfemployment is the identity construct (DiMaggio, 1997) surrounding self-employment which is seen as a male-dominated activity. From this perspective, women are not interested in joining this group since they cannot identify with the predominately male image of entrepreneurship (Davidsson, 1995; Delmar and Davidsson, 2000).

A main shortcoming of research on female entrepreneurs has been the lack of comparative studies with male entrepreneurs (Brush, 1992; Greene et al., 2003) as well as the lack of distinction between different types of female entrepreneurs. In general, the potential effect of family and household composition on entrepreneurship has remained largely overlooked in the literature yet they may play an important role. As a recent study by Justo et al. (2005) has indicated, the parental status of the entrepreneurs can have a significant effect on perceptions of business success. In our paper, we attempt to address this knowledge gap by focusing on entrepreneurs who are parents (both mothers and fathers) in a family setting (i.e. have a partner and dependent children) as well as the influence of the partner's employment status on choice of employment. In this way, we hope to uncover how the family context may affect the choice of either parent (mother or father) in their decision to undertake entrepreneurial activity.

In entrepreneurship research, country context seems to matter. In the US, Reynolds (1997) found two interesting results: that nascent entrepreneurs tended to have more children and individuals who were separated or had never been married were overrepresented in the category of nascent entrepreneurs. However, this was not found to be the case in Sweden even when the authors controlled for gender and pre-school age children (Delmar and Daviddson, 2000). 


\subsection{Labor markets in the European context}

Several researchers have emphasized the influence of institutions on labor market decision-making (See Del Boca and Wetzels, 2007 for an overview). Labor market regulations, low availability of flexible employment arrangements and lack of family policies may contribute to creating difficulties for leaving and re-entering the labor market while becoming a parent and raising children, making the employment adjustment more costly.

In the European context, in spite of recent institutional changes, the southern European labor market still remains a highly regulated one, with strict regulations concerning the hiring and firing of workers and the types of employment arrangements permitted. The hiring system and high entry wages along with very strict firing rules severely restrict employment opportunities for labor market entrants. These labor market regulations have been largely responsible for the high unemployment rates of women and youth.

Given that strict labor market regulations and unemployment discourage exits from the labor market and makes re-entry difficult, women in southern Europe participate less in the labor market and have fewer children (Del Boca, 2002). As a result, women who decide to have a child, despite employment uncertainty and rigidity in working hours, either do not withdraw from the labor market or never re-enter after childbirth.

Analyzing in-kind transfers, it has been shown that the availability of childcare services significantly affects women's preferences for non-market time versus time spent in paid work. Differences emerge among European countries: in southern Europe the childcare services are typically inadequate and characterized by extreme rigidity in the number of weekly hours available. In southern European countries but also in the Netherlands the percentage of children under three who are in childcare is quite low compared with other European countries such as Sweden and Denmark, while the proportion of children over three in childcare is relatively high even compared to northern European countries.

The differences between countries described above help explain the different shapes of the participation rate in the life cycle of women in different countries. In Italy, for example, the participation rate of women decreases more sharply after childbearing years, than in Sweden for example, where the proportion of women working is high, and women enter the labor market in large number when young and stay during childbearing years. In contrast in the UK some women leave during childbearing but come back after a few years (Gustafsson et al., 1996; Wetzels, 2001).

In Table I we describe the labor force participation of mothers before and after having their first child in Spain, Italy and the Netherlands during the period 1994-2001. As table I indicates women's labor force status varies between the three countries.

Table I: Women's labor force status before and after the birth of the first child during (1994-2000) in Spain, Italy and the Netherlands (in percentages)

\begin{tabular}{llllllllll}
\hline Country & Lfpbfr & Lfpyb & Lfpaft & Lfpaft2 & EE & EN & NE & NN & Total \\
\hline Spain & 56.12 & 50.12 & 40.61 & 40.89 & 34.84 & 14.64 & 8.59 & 41.92 & $100.0(198)$ \\
& $(335)$ & $(415)$ & $(362)$ & $(269)$ & & & & & \\
Italy & 52.14 & 50.00 & 49.45 & 48.44 & 42.56 & 12.76 & 9.92 & 34.75 & $100.0(282)$ \\
& $(468)$ & $(614)$ & $(546)$ & $(450)$ & & & & & \\
Netherlands & 83.69 & 86.10 & 70.48 & 72.28 & 65.90 & 19.65 & 7.51 & 6.93 & $100.0(173)$ \\
\hline
\end{tabular}


$(331) \quad(259) \quad(315) \quad(267)$

Total number of respondents in brackets

Lfpbfr = Women's labor force participation rate one survey before giving birth to the first child;

Lfpyb = Women's labor force participation rate in the survey year that the first child is born;

Lfpaft = Women's labor force participation rate one survey after giving birth to the first child;

Lfpaft2 = Women's labor force participation rate two surveys after giving birth to the first child;

$\mathrm{EE}=$ Women who were employed both one survey before and two surveys after birth;

$\mathrm{EN}=$ Women who were employed one survey before birth but not two surveys after;

$\mathrm{NE}=$ Women who were not employed one survey before birth but employed two surveys after birth;

$\mathrm{NN}=$ Women who were not employed either one survey before birth or two surveys after birth.

Source: Based on Author's calculations

\section{Hypotheses}

The general neglect of the potential effect of family composition on the probability for self-employment in entrepreneurship literature is surprising since the relationship between family composition, female labor force status and employment choice has long been a topic of study in the area of labor economics. In fact, one of the most researched areas has been the effect of the presence of young children on female participation in the labor force. Of particular concern has been the effect of child care costs on reducing the likelihood for females to participate in the labor force (Blau and Robins, 1989; Presser and Baldwin, 1980; Del Boca, 2003; Viitanen, 2005; Wetzels, 2005) Generally, the greater the cost of child care relative to the mother's wage potential, the less likely it is she will seek employment.

Perhaps the most comprehensive study to date that has investigated the relationship between female self-employment and her family situation was conducted by Caputo and Dolinsky (1998). Their study was based on data from the 1988 wave of the young woman's cohort of the National Longitudinal Survey of Labor Market Experience (NLSLME) in the US (who in 1988 were aged $33-43$ years) ${ }^{\text {iv }}$. The dependent variable used in the regression estimates was the type of employment the respondent was engaged in 1988 differentiating between earnings from waged employment or self-employment. Their results indicate a strong and significant relationship between the number of under aged children and a woman's choice for self-employment. The husband's self-employed status was also clearly and significantly associated with a woman's choice for selfemployment. Caputo and Dolinsky (1998) propose that the husband's self-employed status is a good proxy for a husband's business knowledge and experience. In addition, a husband's annual self-employed earnings were found to be significant, i.e. higher levels increased significantly the likelihood of women being self-employed. Caputo and Dolinsky (1998) argue that in these cases it seems that the anticipated future earnings from the husband's self-employment appears to be more stable over time than that of the husband's earnings from wages and provides a more secure financial base for the woman's choice to undertake self-employment. They also find that childcare provided by the husband had a positive and significant impact on the wife's choice for selfemployment. Furthermore, women who choose self-employment were more likely to work more hours than women employed in the formal labor market. Many of our subsequent hypotheses will be formulated based on these results.

As indicated by Caputo and Dolinsky's study (1998), husbands who are successful entrepreneurs may serve as role models for their wives as well as providing 
them with support increasing their confidence to pursue entrepreneurship. An additional explanation has been formulated by Bruce (1999) based on US Panel Study of Income Dynamics (PSID) that the presence of a self-employed husband enabled intra-family flows of financial and human capital and encouraged females to become self-employed. Other authors have pointed to the importance of mentors and role models for the pursuit of entrepreneurship (Naffziger et al., 1994; Shapero, 1984). In our study, we propose to broaden the analysis to include cohabitating male partners as well as husbands. Based on these results, we formulate our first hypothesis:

H1 - Mothers whose partners are self-employed are more likely to choose selfemployment.

The different financial and human capital resources which husbands may possess, may also affect the woman's choice between wage employment and self-employment. Caputo and Dolinsky (1998) propose that an increased level of income would enable a woman to raise the necessary capital to start-up her own business and to endure more easily the financial risk associated with being self-employed. However, their research results do not provide evidence for this claim. Connelly (1992) examined the effects of other household income on the likelihood of women being self-employed in Canada and found a significant positive effect. Based on these results, we formulate our second hypothesis:

H2 - Mothers from households with higher levels of household income will more likely choose self-employment.

In addition to examining the effect of the partner's employment type, we also investigate the possible effect of a non-working male partner (i.e. unemployed partner) on the likelihood that a mother will choose self-employment. We would expect the possibility to better combine home and work responsibilities to influence the mother's choice for self-employment. Therefore hypothesis three reads:

H3 - Unemployed partners will act as a catalyst for mothers to choose self-employment since it is easier for them to combine home and work responsibilities in this way.

The human capital of adult relatives in the household may also exert a positive effect on female self-employment. Caputo and Dolinsky (1998) test this influence and report positive but not significant results. However, other studies have indicated that the presence of different relatives in the household is a source of informal childcare (Heckman, 1974; Presser, 1986). Given the evidence that self-employment is a means to better balance household and family responsibilities than formal employment, our fourth hypothesis states:

H4 - Unpaid childcare assistance (in the form of adult relatives residing in the household) will have less impact for self-employed mothers since self-employment allows them to better combine home and work responsibilities than for their formally employed counterparts. 
It is often mentioned in the literature, that women who have left formal employment to raise their children will have a more difficult time re-entering the formal labor force (Wetzels and Tijdens, 2002). As a result, some mothers may choose selfemployment as an alternative to formal employment. Hypothesis five addresses this issue:

H5 - Mothers who were unemployed before their current occupation will more likely choose self-employment as an alternative means for re-entering the paid labor force than mothers who remained employed.

Hypothesis six tests the influence of a young child (or children) in the household on the choice for mother's self-employment. Previous studies such as Caputo and Dolinsky (1998) have indicated that this relationship is positive. Additionally, a further US study conducted by Boden (1999) has found that women were more likely to cite flexibility of schedule and family related reasons for becoming self-employed while men's reasons showed little association with their parental status. Since under-aged children ${ }^{\mathrm{v}}$ would conceivable form the greatest burden for mothers we formulate hypothesis six to focus on this specific situation:

H6 - Mothers with more under-aged children will be more likely to choose selfemployment than mothers with fewer under-aged children.

Finally, we are interested in investigating if self-employment also permits mothers to work fewer hours (i.e. part-time instead of full-time) and if this has a strong influence on the choice to become self-employed:

H7 - The possibility to work fewer hours when self-employed will influence a mother's choice for self-employment

Putting these motivations into a contemporary theoretical context as proposed by Lee and Venkataraman (2006), family responsibilities could form part of the 'aspiration vector' ${ }^{\text {vi }}$ while the labor market's reaction to mothers seeking formal employment could form part of the 'market offering vector' ${ }^{\text {vii }}$. As Lee and Venkataraman argue both vectors are important in understanding why people seek entrepreneurial opportunities and under what conditions is the pursuit of entrepreneurial opportunity most likely. For parents, especially mothers both aspirations and market offering seem to contribute to the final choice of self-employment.

Caputo and Dolinsky’s study (1998) provides some very important insights into the influence of household composition on a woman's choice for self-employment. However, one of the main limitations of this study (and similar studies) is the lack of comparative information regarding the male partner. In our study we are interested in investigating the possible significance of parenthood (both as mothers and fathers) within a family context on an individual's choice for self-employment. Though all these hypotheses are formulated to address the woman in the role of mother, we also examine all seven hypotheses for the male partner i.e. father and compare the results. 


\section{Data and Methodology}

In this paper, we empirically analyze the choice between self-employment and gainful employment ${ }^{\text {viii }}$ of parents. We have chosen to compare three different European countries since context does seem to matter in terms of gender differences ${ }^{\text {ix }}$ as well as in terms of other characteristics ${ }^{\mathrm{x}}$. For our empirical analysis we use the European Community Household Panel (ECHP), a longitudinal survey coordinated and supported by the Eurostat (Eurostat, 1999, 2002). The survey involves a representative sample of households and individuals interviewed for eight years (1994-2001) in each of the fifteen countries $^{\mathrm{xi}}$. The standardized methodology and procedure in data collection yield comparable information across countries, making the ECHP a unique source of information for cross-country analysis at the European level. The aim of the survey, in fact, is to provide comparable information on the population of the EU, representative both at the longitudinal and the crosswise level.

The data collected cover a wide range of topics on living conditions (income, employment, poverty and social exclusion, housing, health, migration, and other social indicators). Therefore the ECHP survey allows for the analysis of how individuals and households experience change in their socio-economic environment and how they respond to such changes as well as for the analysis of how conditions, life events, behavior, and values are linked to each other dynamically over time.

The unit of analysis of the ECHP are families and, within the households, all individuals older than 16 , though it is possible to obtain information (mainly demographic information) for children under 16 years of age. This data set is the only source in Europe with comparable information on the labor market and households for fifteen European countries in the period 1994-2001. The use of this interesting dataset, however, also includes some limitations. One of the most crucial issue concerns the high incidence of missing values, (for example education variables) ${ }^{\text {xii }}$. We have selected three countries (Spain, Italy and the Netherlands) since not only do they represent different regions and socio-economic systems but also all relevant information for our analysis is available in sufficient observations in the most recent year available 2001.

\subsection{The model}

In order to estimate the effects of individual, household, and environmental characteristics on the decision to work as self-employed or in gainful employment, we use a logit estimation model. The econometric specification of the decision for selfemployment is assumed to be quasi-reduced form representations of the demand functions representing the solutions to the optimization problem. A latent variable structure is assumed for the decision. To illustrate this, we consider the following equation. Let the net value of being self-employed in period t be given by:

$$
P_{1, t}^{*}=H_{i, t} \beta_{1}+Y_{i, t} \beta_{2}+E_{i, t} \beta_{3}+u_{i, t}
$$

where $H_{i, t}$ is the row vector containing the observed variables measuring the household $i$ parent's human capital at time $t, Y_{i, t}$ is the vector of household's income at time $t$ and it includes the partner's earnings and $E_{i, t}$ is the vector of variables describing the economic environment (labor market characteristics). The term $u_{i, t}$ is a disturbance term. The 
dependent variable is defined as $d_{i, t}^{p}=1$ if the parent in the household $i$ participates in paid employment through self-employment ${ }^{\text {xiii }}$ in period $t$, and set $d_{i, t}^{p}=0$ if the parent chooses for gainful employment. We perform this analysis for mothers and fathers separately.

\subsection{Data and variables}

For our empirical analysis we selected three of the fifteen countries from the Eurostat dataset that are representative of the countries with limited child care facilities for small children: Italy, Spain and The Netherlands. For these three countries we consider the data relative to the year 2001. Both the choice of the year and the choice of the countries were limited due to the availability of relevant information on independent variables.

For our analysis we selected mothers in the age range 21-55 years, married or cohabitant, in order to exclude those women who might still be enrolled in school or may already be retired, similarly we select fathers in the age range 21-55 years. The age restriction helps to ensure that parents included in the final sample will have a high probability of having children in ages which are time consuming for parents ${ }^{\text {xiv }}$. Our aim is to estimate the probability of a parent being self-employed. The dependent variables used in our analysis are therefore whether the mother and father is self-employed working at the time of the interview with the base category being gainfully employed.

The independent variables we use to explain the mother's or father's decision can be divided in three main groups and are shown in table II:

Table II: Independent variables defined

\begin{tabular}{lll}
\hline Category & Variable & Description \\
\hline $\begin{array}{l}\text { Personal Characteristics: } \\
\text { Human Capital }\end{array}$ & (1) Respondent's age & Continuous variable \\
& (2) Respondent's education & $\begin{array}{l}\text { Three dummy variables are used: tertiary } \\
\text { level education, secondary level of } \\
\text { education, and less than secondary level of } \\
\text { education. The latter level is used as the } \\
\text { base category. }\end{array}$ \\
& (1) Number of children & $\begin{array}{l}\text { Categorical variable indicating number of } \\
\text { children in household: } 1=0 n e \text { child in } \\
\text { household; } 2=\text { two children in household; } \\
\text { 3=three children in household; } 4 \text { - } 4 \text { and } \\
\text { Characteristics }\end{array}$ \\
& $\begin{array}{l}\text { more children in household; } 0 \text { if no } \\
\text { children in household; }\end{array}$
\end{tabular}

(2) Age of children present in the household:

(3) Presence of grandmother
Continuous variables indicating the age of the first child; the age of the second child and the age of the third child; Otherwise 0 if no second child is present; 0 if no third child is present.

The presence in the household of either the 
mother's or the father's mother.

(4) Total net household income from work

(5) Household's ability to make ends meet
Total for year prior to the survey (in euros and divided by 1000).

Categorical variable: How easy is it for your household to make ends meet? 1 = great difficulty, 2=difficulty; $3=$ some difficulty; 4=fairly easily; 5=easily; 6= very easily.
Labor market characteristics
(1) Part-time employment status

(2) Status before current employment is unemployed

(3) Partner's working hours

(4) Partner's self- employment status

(5) Partner's non-employment status
35 hours or less worked per week, zero otherwise.

Dummy variable: 1 = respondent is unemployed, zero otherwise. Continuous variable: Total hours worked by partner for pay per week.

Dummy variable: 1 = partner is selfemployed, zero otherwise. Dummy variable: 1 = partner is unemployed, zero otherwise.

The information concerning income has been made comparable using PPP specific coefficients provided by Eurostat in the ECHP dataset. In our empirical analysis we consider the effect of all variables mentioned above on the probability of a parent in self-employment as compared with the parent being in gainful employment. Table A.I in the appendix reports the descriptive statistics for the sample used divided by countries.

The descriptive statistics presented in table III, show a picture quite coherent with the empirical evidence discussed in the previous sections. The percentage of selfemployed mothers is higher in Spain and Italy, while it is much lower in the Netherlands.

The comparison of the labor market characteristics indicates that the percentage of part-time workers is particularly low in the southern European countries, working parttime is widespread in the Netherlands.

The family structure shows different features across countries: the percentage of households where we observe a grandmother living with the parents and children is relevant only in southern European countries where the lack of public services and perhaps tradition makes the role of the extended family important.

Table III: Characteristics of self-employed parents: Means and Standard Deviation (in parentheses)

\begin{tabular}{|c|c|c|c|c|c|c|}
\hline \multirow[t]{2}{*}{ Variable* } & \multicolumn{2}{|l|}{ Spain } & \multicolumn{2}{|l|}{ Italy } & \multicolumn{2}{|c|}{ Netherlands } \\
\hline & $\begin{array}{l}\text { Mothers } \\
\mathrm{N}=126\end{array}$ & $\begin{array}{l}\text { Fathers } \\
\mathrm{N}=364\end{array}$ & $\begin{array}{l}\text { Mothers } \\
\mathrm{N}=199\end{array}$ & $\begin{array}{l}\text { Fathers } \\
\mathrm{N}=611\end{array}$ & $\begin{array}{l}\text { Mothers } \\
\mathrm{N}=70\end{array}$ & $\begin{array}{l}\text { Fathers } \\
\mathrm{N}=121\end{array}$ \\
\hline Age (yrs) & $\begin{array}{l}41.33 \\
(7.679)\end{array}$ & $\begin{array}{l}42.17 \\
(7.17)\end{array}$ & $\begin{array}{l}41.48 \\
(7.773)\end{array}$ & $\begin{array}{l}41.95 \\
(7.231)\end{array}$ & $\begin{array}{l}41.56 \\
(7.240)\end{array}$ & $\begin{array}{l}42.33 \\
(7.302)\end{array}$ \\
\hline Tertiary education & 0.17 & 0.17 & 0.09 & 0.122 & 0.21 & 0.11 \\
\hline Secondary education & 0.18 & 0.22 & 0.39 & 0.33 & 0.49 & 0.07 \\
\hline Married & 0.97 & 0.97 & 0.96 & 0.98 & 0.94 & 0.96 \\
\hline Grandmother & 0.18 & 0.11 & 0.07 & 0.05 & \& & \& \\
\hline Partner - & 0.50 & 0.15 & 0.49 & 0.15 & 0.34 & 0.18 \\
\hline
\end{tabular}




\begin{tabular}{|c|c|c|c|c|c|c|}
\hline $\begin{array}{l}\text { self-employed } \\
\text { Partner - } \\
\text { not working }\end{array}$ & 0.13 & 0.59 & 0.13 & 0.56 & 0.03 & 0.34 \\
\hline $\begin{array}{l}\text { Partner - } \\
\text { work hours }\end{array}$ & $\begin{array}{l}44.73 \\
(21.831)\end{array}$ & $\begin{array}{l}17.67 \\
(21.862)\end{array}$ & $\begin{array}{l}39.78 \\
(19.864)\end{array}$ & $\begin{array}{l}16.220 \\
(18.99)\end{array}$ & $\begin{array}{l}46.90 \\
(16.801)\end{array}$ & $\begin{array}{l}19.369 \\
(19.334)\end{array}$ \\
\hline $\begin{array}{l}\text { Re-entering work } \\
\text { force }\end{array}$ & 0.28 & .25 & 0.24 & 0.21 & 0.11 & 0.14 \\
\hline $\begin{array}{l}\text { Age started working } \\
\text { (yrs) }\end{array}$ & $\begin{array}{l}21.02 \\
(9.554)\end{array}$ & $\begin{array}{l}16.17 \\
(4.693)\end{array}$ & $\begin{array}{l}22.08 \\
(10.711)\end{array}$ & $\begin{array}{l}19.00 \\
(7.333)\end{array}$ & $\begin{array}{l}22.13 \\
(8.515)\end{array}$ & $\begin{array}{l}18.98 \\
(6.349)\end{array}$ \\
\hline Part-time work & 0.24 & 0.04 & 0.27 & 0.04 & 0.75 & 0.10 \\
\hline $\begin{array}{l}\text { Household finance } \\
(1-6)\end{array}$ & $\begin{array}{l}3.53 \\
(0.960)\end{array}$ & $\begin{array}{l}3.32 \\
(1.257)\end{array}$ & $\begin{array}{l}3.39 \\
(1.274)\end{array}$ & $\begin{array}{l}3.21 \\
(1.447)\end{array}$ & $\begin{array}{l}4.48 \\
(1.050)\end{array}$ & $\begin{array}{l}4.32 \\
(1.061)\end{array}$ \\
\hline $\begin{array}{l}\text { Household income } \\
\text { (Euro/1000) }\end{array}$ & $\begin{array}{l}21.09 \\
(16.290)\end{array}$ & $\begin{array}{l}21.58 \\
(15.712)\end{array}$ & $\begin{array}{l}24.66 \\
(17.390)\end{array}$ & $\begin{array}{l}21.71 \\
(14.273)\end{array}$ & $\begin{array}{l}30.74 \\
(17.671)\end{array}$ & $\begin{array}{l}28.42 \\
(19.141)\end{array}$ \\
\hline Number of children & $\begin{array}{l}2.02 \\
(0.856)\end{array}$ & $\begin{array}{l}1.96 \\
(0.742)\end{array}$ & $\begin{array}{l}1.70 \\
(0.687)\end{array}$ & $\begin{array}{l}1.82 \\
(0.762)\end{array}$ & $\begin{array}{l}2.07 \\
(0.748)\end{array}$ & $\begin{array}{l}2.21 \\
(0.947)\end{array}$ \\
\hline Age $1^{\text {st }}$ child & $\begin{array}{l}16.67 \\
(8.087)\end{array}$ & $\begin{array}{l}15.29 \\
(7.801)\end{array}$ & $\begin{array}{l}16.39 \\
(8.657)\end{array}$ & $\begin{array}{l}13.52 \\
(8.142)\end{array}$ & $\begin{array}{l}14.40 \\
(6.332)\end{array}$ & $\begin{array}{l}13.21 \\
(6.512)\end{array}$ \\
\hline Age $2^{\text {nd }}$ child $* *$ & $\begin{array}{l}10.60 \\
(9.508)\end{array}$ & $\begin{array}{l}9.50 \\
(8.676)\end{array}$ & $\begin{array}{l}7.55 \\
(9.353)\end{array}$ & $\begin{array}{l}7.22 \\
(8.516)\end{array}$ & $\begin{array}{l}8.84 \\
(7.286)\end{array}$ & $\begin{array}{l}7.62 \\
(7.156)\end{array}$ \\
\hline Age $3^{\text {rd }}$ child ${ }^{* *}$ & $\begin{array}{l}2.04 \\
(6.771)\end{array}$ & $\begin{array}{l}1.69 \\
(6.208)\end{array}$ & $\begin{array}{l}.19 \\
(4.551)\end{array}$ & $\begin{array}{l}.95 \\
(5.228)\end{array}$ & $\begin{array}{l}1.53 \\
(5.061)\end{array}$ & $\begin{array}{l}2.80 \\
(5.738)\end{array}$ \\
\hline
\end{tabular}

Key:

* = For a description of these variables please refer to Table I.

$\stackrel{*}{*}$ too few observations.

ISCED = International Standard Classification of Education (ISCED) designed by UNESCO in 1997.

\# = includes partner is not working.

Means, total number and standard deviation (in parenthesis) for the partner's working hours if partner is in paid work:

\begin{tabular}{lll}
\hline & women & men \\
\hline Spain & $51.24 \mathrm{~N}=110(15.0)$ & $40.25 \mathrm{~N}=161(13.35)$ \\
Italy & $46.56 \mathrm{~N}=170(12.00)$ & $33.95 \mathrm{~N}=281(12.15)$ \\
Netherlands & $48.32 \mathrm{~N}=66(14.87)$ & $26.55 \mathrm{~N}=89(17.92)$ \\
\hline
\end{tabular}

** indicates that it includes households not having a second child, not having a third child respectively.

Means, total number and standard deviation (in parenthesis) for women having a second child. The age of the second child:

\begin{tabular}{lll}
\hline & women & men \\
\hline Spain & $14.71 \mathrm{~N}=91(7.58)$ & $13.17 \mathrm{~N}=272(7.05)$ \\
Italy & $13.42 \mathrm{~N}=118(7.91)$ & $12.01 \mathrm{~N}=363(7.22)$ \\
Netherlands & $11.53 \mathrm{~N}=55(5.80)$ & $10.82 \mathrm{~N}=89(5.67)$ \\
\hline
\end{tabular}

Means, total number and standard deviation (in parenthesis) for women having a second child. The age of the third child:

\begin{tabular}{lll}
\hline & women & men \\
\hline Spain & $25.65 \mathrm{~N}=23(4.85)$ & $13.47 \mathrm{~N}=68(6.05)$ \\
Italy & $12.17 \mathrm{~N}=18(8.59)$ & $14.16 \mathrm{~N}=92(6.78)$ \\
Netherlands & $8.83 \mathrm{~N}=18(5.28)$ & $8.65 \mathrm{~N}=48(5.21)$ \\
\hline
\end{tabular}

\section{Results and Discussion}

As presented in table IV, we estimate the probability of self-employment for parents with a logit model. The results show that age has a positive effect on the 
probability of being self-employed, for mothers only in the Netherlands. This result for mothers in the Netherlands is in line with previous findings by Gustafsson et al (2003) based on a pooled regression using national household panel data. Gustafsson et al (2003) find that older women and men are more likely to be in self-employment (as opposed to being in full-time permanent employment) as compared to younger women and men. The differences in our results may be attributed to the difference between parents versus the general population.

In terms of education, having obtained more than an upper secondary education has a negative effect on the probability of being self-employed in Spain for mothers and fathers and mothers in Italy compared to the base category which is less than upper secondary education. This is also in line with the descriptive statistics presented in Cebrian et al. (2003:109), which show that self-employment in Spain is more prevalent among lower educated men and women. Based on ECHP data for Spain and Portugal Garcia-Mainar and Montuenga-Gomez (2005) find that secondary education is the most valuable type of schooling for self-employed individuals whereas higher education is most valuable for employees. However, in Italy secondary education as compared to less than secondary education decreases the probability for parents to be self-employed, whereas in the Netherlands it increases the probability of self-employment for fathers of choosing self-employment as opposed to gainful employment. Unemployment before current job has a negative effect on self-employment for mothers and fathers in Spain and mothers in Italy. A later start in working life has a positive effect on being a selfemployed mother only in Spain, yet a negative effect on self- employed fathers in Spain. Net household income has the expected negative sign on the probability of being selfemployed of mothers in Spain and fathers in Italy.

In terms of our first hypothesis that mothers (and fathers) whose partners are selfemployed are more likely to become self-employed, we find strongly significant results for all three countries in support of this hypothesis. These results are in line with Caputo and Dolinsky (1998) and Connelly (1992). We also find very strong evidence that this holds true for fathers. For Spain and the Netherlands, the likelihood is even higher for fathers than for mothers. These results seem to indicate that partner's self-employment status regardless of whether they are male or female, has a strongly positive influence on the other partner's choice of self-employment in a family context. This supports the notion that self-employment may have additional benefits for couples in a family context.

Our results show no evidence in support of hypothesis two which stipulates that mothers from households with higher levels of household income will more likely be self-employed. Though few of the coefficients are significant for this variable, the tendency indicates a negative relationship: that as income increases the likelihood for choosing self-employment diminishes. This is found to be significant for mothers in Spain and fathers in Italy. These results contradict earlier findings based on Canadian data by Connelly (1992) and may be related to the probability of earning an income below poverty in Italy and Spain. The analyses presented in Cebrian et al. (2003) which is based on data from 1995 shows that in Italy 14.9 per cent of the self-employed have a monthly household income in adult equivalent per capita terms below the poverty line compared with only 6.2 percent of full-time employees with a permanent contract. In Spain 22.6 per cent of self-employed have a monthly household income in adult equivalent per capita terms below the poverty line compared with only 4.5 percent of 
full-time employees with a permanent contract. Unfortunately this study does not provide information on female and male self-employed and no information is given on family composition.

Furthermore, in terms of household finance, we find that this has a significant and positive effect for mothers and fathers in Spain and for fathers in Italy. It does not have a significant effect in the Netherlands. Since these results are not gender-specific but seem to vary according to country context they may well be an indication of the influence of financial support for entrepreneurship and business development as well as differing market structure.

Our results provide further support for hypothesis three. In almost all cases, for both mothers and fathers we find a strongly significant and positive relationship between a partner's unemployed status and the other partner's (either father's or mother's) likelihood to choose self-employment. The exception are mothers in the Netherlands where the sign is also positive but not significant. This result supports Caputo and Dolinsky's (1998) findings for married women. If we had only obtained significant results for mothers than we could expect it to indicate that it is easier to combine childcare with self-employment and so when mothers feel pushed into paid labor, due to the unemployed status of their partner, then self-employment would be the most attractive alternative. This may be the case in Spain where the coefficient for this variable is especially high. However, an alternative explanation for this high significance for Spanish women could be due to the fact that the Spanish labor market is the most rigid with the highest percentage of fixed term, short period contracts. This means that employed persons (including employed parents) have difficulties finding secure permanent positions on the Spanish labor markets. This may mean that, as a result, Spanish mothers are more inclined to choose self-employment. Taking these factors into account, we believe that our results paint a more complex picture than initially expected. In addition, men are more likely to be self-employed than gainfully employed if their partner is not working for pay.

In addition, all three countries have social policy regimes that are dominated by the male "breadwinner" role model. There has been some improvement in the Netherlands since the 1990s, however this mentality still characterizes the social policies and labor market features predominant in Spain and Italy. The fathers in our sample, seem to be reacting to this cultural role. Since self-employed men work longer hours than men with an employment contract they may also feel a need that their female partner takes care of household tasks. Since childcare is relatively expensive in the Netherlands and women tend to work in short part-time jobs, the combination of self-employed fathers with unpaid caring mothers may constitute an optimal division of labor.

In terms of testing the fourth hypothesis regarding unpaid childcare assistance as proxied by the presence of a grandmother in the household, our results for Spain generally support our hypothesis. However, in Spain is the presence of a grandmother in the household found to significantly increase the likelihood of mothers and fathers to choose self-employment. Too few observations of a grandmother in the household were available for the Netherlands in order to test this hypothesis empirically, indicating that a grandmother's presence in the household is exceptional in Dutch homes.

Our regression results provide no support for hypothesis five which anticipated mothers who were unemployed to more likely to become self-employed as an alternative 
means to re-entering the paid labor force than mothers employed in the formal labor force. The result is positive but not significant for mothers and fathers in the Netherlands, while negatively significant for mothers in and fathers in Spain and fathers in Italy. This result seems to indicate that self-employment is therefore not necessarily an alternative for mothers to reenter the labor force in Spain and Italy. A surprising result is the fact that Dutch mothers and fathers are significantly more likely to reenter the labor force through self-employment. This may be related to policies in the Netherlands geared to help the unemployed to start their own business. Further analysis of this issue is needed.

Table IV: Logistic Regression: Dependent variable: choice for self-employment

\begin{tabular}{|c|c|c|c|c|c|c|}
\hline \multirow[t]{2}{*}{ Independent variable } & \multicolumn{2}{|c|}{ Spain } & \multicolumn{2}{|c|}{ Italy } & \multicolumn{2}{|c|}{ Netherlands } \\
\hline & Mothers & Fathers & Mothers & Fathers & Mothers & Fathers \\
\hline \multirow[t]{2}{*}{ age } & 0.042 & 0.013 & 0.003 & 0.017 & 0.103 & 0.013 \\
\hline & $(0.031)$ & $(0.017)$ & $(0.024)$ & $(0.014)$ & $(0.037)^{* * *}$ & $(0.027)$ \\
\hline \multirow[t]{2}{*}{ Tertiary education } & -0.935 & -0.371 & -0.794 & 0.213 & -0.425 & 0.437 \\
\hline & $(0.345)^{* * *}$ & $(0.211)^{*}$ & $(0.335)^{* *}$ & $(0.203)$ & $(0.413)$ & $(0.416)$ \\
\hline \multirow[t]{2}{*}{ Secondary education } & -0.431 & -0.030 & -0.693 & -0.291 & -0.231 & 1.017 \\
\hline & $(0.324)$ & $(0.172)$ & $(0.194)^{* * *}$ & $(0.122)^{* *}$ & $(0.340)$ & $(0.472)^{* *}$ \\
\hline \multirow[t]{2}{*}{ Married } & 0.383 & -0.330 & -0.671 & -0.147 & 0.109 & 0.657 \\
\hline & $(1.000)$ & $(0.531)$ & $(0.596)$ & $(0.399)$ & $(0.566)$ & $(0.544)$ \\
\hline \multirow[t]{2}{*}{ Grandmother } & 1.084 & 0.386 & 0.184 & 0.117 & $\bullet$ & $\diamond$ \\
\hline & $(0.352)^{* * *}$ & $(0.230)^{*}$ & $(0.379)$ & $(0.237)$ & & \\
\hline \multirow[t]{2}{*}{ Partner self-employed } & 1.495 & 1.571 & 1.383 & 1.346 & 1.766 & 1.948 \\
\hline & $(0.282)^{* * *}$ & $(0.274) * * *$ & $(0.216)^{* * *}$ & $(0.205) * * *$ & $(0.355)^{* * *}$ & $(0.339)^{* * * *}$ \\
\hline \multirow[t]{2}{*}{ Partner not working } & 2.093 & 1.212 & 0.854 & 0.650 & 1.046 & 1.185 \\
\hline & $(0.679)^{* * *}$ & $(0.335)^{* * *}$ & $(0.468)^{*}$ & $(0.277)^{* *}$ & $(0.956)$ & $(0.342)^{* * *}$ \\
\hline Partner's total hours & 0.034 & 0.029 & 0.015 & 0.013 & 0.029 & 0.048 \\
\hline worked per week & $(0.013)^{* *}$ & $(0.008) * * *$ & $(0.009)$ & $(0.007)^{*}$ & $(0.011)^{* * *}$ & $(0.010)^{* * * *}$ \\
\hline unemployed before & -0.469 & -0.293 & -0.313 & -0.318 & 0.419 & 0.226 \\
\hline current job & $(0.257)^{*}$ & $(0.152)^{*}$ & $(0.200)$ & $(0.130)^{* *}$ & $(0.398)$ & $(0.317)$ \\
\hline \multirow[t]{2}{*}{ age started working } & 0.030 & -0.044 & 0.015 & -0.010 & -0.003 & -0.020 \\
\hline & $(0.013)^{* *}$ & $(0.018)^{* *}$ & $(0.011)$ & $(0.008)$ & $(0.016)$ & $(0.018)$ \\
\hline Part-time work (35 & -0.872 & -0.702 & -0.491 & -0.621 & -0.976 & 0.009 \\
\hline hours or less) & $(0.266)^{* * *}$ & $(0.321)^{* *}$ & $(0.197)^{* *}$ & $(0.259)^{* *}$ & $(0.377)^{* * *}$ & $(0.372)$ \\
\hline Household able to & 0.315 & 0.176 & -0.001 & 0.139 & -0.011 & -0.041 \\
\hline make ends meet? & $(0.110)^{* * *}$ & $(0.088)^{* *}$ & $(0.103)$ & $(0.078)^{*}$ & $(0.166)$ & $(0.112)$ \\
\hline total net hh work & -0.038 & -0.003 & -0.011 & -0.016 & 0.004 & -0.001 \\
\hline income & $(0.012)^{* * *}$ & $(0.006)$ & $(0.010)$ & $(0.007)^{* *}$ & $(0.003)$ & $(0.005)$ \\
\hline Number of children & 0.348 & 0.320 & 0.530 & 0.257 & 0.721 & 0.667 \\
\hline in household & $(0.290)$ & $(0.169)^{*}$ & $(0.246)^{* *}$ & $(0.131)^{* *}$ & $(0.370)^{*}$ & $(0.283)^{* *}$ \\
\hline \multirow[t]{2}{*}{ Age of $1^{\text {st }}$ child } & -0.033 & -0.008 & 0.033 & -0.027 & -0.056 & 0.008 \\
\hline & $(0.034)$ & $(0.019)$ & $(0.022)$ & $(0.014)^{*}$ & $(0.033)^{*}$ & $(0.031)$ \\
\hline \multirow[t]{2}{*}{ Age of $2^{\text {nd }}$ child } & 0.015 & 0.008 & -0.035 & -0.006 & -0.001 & -0.075 \\
\hline & $(0.025)$ & $(0.016)$ & $(0.017)^{* *}$ & $(0.012)$ & $(0.029)$ & $(0.026)^{* * *}$ \\
\hline \multirow[t]{2}{*}{ Age of $3^{\text {rd }}$ child } & -0.024 & -0.015 & -0.062 & -0.007 & -0.094 & 0.036 \\
\hline & $(0.029)$ & $(0.016)$ & $(0.028) * *$ & $(0.015)$ & $(0.051)^{*}$ & $(0.037)$ \\
\hline \multirow[t]{2}{*}{ Constant } & -6.202 & -2.828 & -2.637 & -1.895 & -8.064 & -5.372 \\
\hline & $(1.735)^{* * *}$ & $(0.886) * * *$ & $(1.263)^{* *}$ & $(0.705) * * *$ & $(1.995)^{* * *}$ & $(1.250)^{* * *}$ \\
\hline Observations & 751 & 1,579 & 1,132 & 2,044 & 1,090 & 1,327 \\
\hline Log likelihood & -256.200 & -743.993 & -446.145 & -1094.789 & -190.206 & -298.646 \\
\hline Pseudo R squared & 0.23 & 0.08 & 0.13 & 0.05 & 0.17 & 0.14 \\
\hline Wald ch(2) 17 & 123.05 & 92.76 & 132.75 & 91.54 & 78.15 & 93.07 \\
\hline
\end{tabular}

Key:

- = too few observations. Standard errors in parentheses. * significant at 10\%; ** significant at 5\%; *** significant at $1 \%$. Prob $>$ chi squared 0.00 . 
Hypothesis six which considers the impact of the presence of a young child or more young children also leads to mixed results in terms of the choice for selfemployment. The presence of a young child in the household increases the probability of being self-employed for Italian mothers and Dutch fathers. For Italian fathers, a younger first child significantly affects the probability for self-employment while for Italian mothers, younger second or third children have a significantly positive effect. However, for Dutch fathers a young second child has a significantly positive effect while for Dutch mothers a third child has a significantly positive effect on the probability for selfemployment. DeMartino and Barbato’s (2003) study indicated that married female entrepreneurs with dependent children were mainly motivated to go into business to balance family and business responsibilities and this was not found to be the case for married men. But our results indicate that it seems to have an effect especially as the number of dependent children increases to two or three children. Similarly, Gustafsson et al. (2003) found that men in Britain, Germany, the Netherlands and the U.K. were more likely to be self-employed as compared to full-time paid employment if they had two children or more but there was no effect of having only one child or no child in the household.

We find support for hypothesis six which expected mothers with more children to be more likely to be self-employed than mothers with fewer under aged children. This holds true for having a second or third young child for mothers in Italy and for having a third young child for mothers in the Netherlands. We did not find any significant effects for mothers in Spain. The results for mothers are in line with Caputo and Dolinsky (1998) and Hildebrand and Williams (2003) but the additional information gathered from our regressions is that the presence of young children also has a positive effect for the father's choice for self-employment in the Netherlands and in Italy.

In countries where part-time work is widespread (such as in the UK), this form of employment often reflects low-qualified and/or poorly paid jobs and mostly temporary positions, however in the Netherlands which has the highest part-time employment rate for women and for men in Europe, part-time work is not solely restricted to a particular group of workers in the labor market, although women are more likely to be in part-time work than men (Gustafsson et al., 2003; Wetzels, 2001). In countries where part-time work is very limited such as in Spain and Italy, part-time is also, as in the Netherlands, characterized by similar job protection and social benefits as full-time jobs and it consists mainly of permanent positions and middle-level job qualifications. Our regression results indicate that for mothers in Spain, Italy and the Netherlands and for fathers in Spain and Italy, part-time is significant and negative indicating that self-employment is not a parttime affair. This leads us to reject hypothesis seven. These results not only support Caputo and Dolinsky's study (1998) which showed that women who choose selfemployment were more likely to work more hours than women employed in the formal labor market but expand these results to show that this also holds true for fathers.

Finally, though some earlier studies such as DeMartino and Barbato (2003) have indicated that married women are more likely to become entrepreneurs, we do not find that to be the case in our results when we compare self-employed mothers to gainfully employed mothers. In DeMartino and Barbato's research, the women studied were all characterized by a high level of human capital (MBA graduates). In our study, the sample 
represented a wide array of human capital capabilities and therefore seems to indicate that in the population as a whole, when a married mother is engaged in paid labor the likelihood that she will choose self-employment over formal employment is not significant. This result was also found not to be significant for fathers.

\section{Discussion and Conclusion}

In this paper, we analyze the potential influence of household composition and parenthood in a family setting on the choice for self-employment in a European context. Though a number of existing studies have indicated that female entrepreneurship is a means for mothers to balance their work and family responsibilities, little empirical work has been conducted which includes the influence of fatherhood and partner's employment status in the analysis. In addition, most studies investigating similar issues have been based on North American data. This paper addresses these issues in the broader European context by including data from Spain, Italy and the Netherlands. Specifically, we compare the probability that a mother or father will choose self-employment or gainful employment as influenced by the presence of children as well as by other personal, household and labor market characteristics.

Our results show that in all three country contexts the choice for self-employment by mothers is significantly influenced by a self-employed male partner. Furthermore, the choice for self-employment is not associated with fewer working hours. These results indicate that though mothers may choose self-employment as a means to combine work with childcare, they are not spending less hours at work as a result of it.

Correspondingly, our results for fathers indicates that the choice for selfemployment by fathers is significantly influenced by a self-employed female partner or partner not working and increased working hours of the partner. Having an unemployed partner has a positive effect of self employment for both gender.

We also find some clear country differences. In Spain, self-employment was found to be negatively associated with higher levels of education for both gender, whereas in Italy and the Netherlands higher education is only negatively associated with self-employment for mothers while higher education is positively but not significantly associated with self-employment for fathers. In addition, the age at which mothers started working in Spain was also found to be significantly older as related to the choice for selfemployment than women working in the formal labor force indicating that age (a proxy for experience) is important for women in establishing themselves as self-employed in these labor markets. For women it may be the case that they would not choose selfemployment or even view self-employment as an option at the beginning of their careers. Women in Spain tend to invest more in schooling, stay longer in school and may encounter more difficulties finding a job after completing schooling than women in other countries and as compared to their male counterparts. But the women who enter the labor market later, may be additionally motivated to earn a living and learn how to become self-employed as compared to women who start work early but in an 'easier, less human capital intensive job'. This notion fits with the necessity for having diverse qualifications for becoming self-employed (the advantages of being a 'generalist' as discussed by Lazear 2004). For fathers in Spain, however, we find that if they enter into working life later in their lives, they are less likely to become self-employed. This may be related to education as well. With men, the wealth motivation seems to play a decisive role in 
career choice. In addition, the presence of more children as well as the presence of younger multiple children had no effect for Spanish mothers or fathers but has a positive effect on the choice for self-employment in Italy and the Netherlands.

In the Netherlands, we identified a negative effect for both mothers and fathers to choose self-employment when they have either an older first child or third child. This may indicate that Dutch women may choice for self-employment when the first child is very young since maternity leave is based on the European minimum standard and parental leave is three months but in most cases unpaid and that with multiple young children, external childcare costs become prohibitively high combined with the increased burden of the Dutch school system ${ }^{\mathrm{xv}}$. In Italy this is also the case for mothers with young second or third children. The few effects of the age of children on father's choice for selfemployment seem not related to care arrangements. In Spain we do not find any effects of age of children on the choice for self-employment which seems to point out that cross country differences account for the effects of children. However, it is important to note that in both Italy and Spain there are less families with three children. As a result, there is a greater tendency for one-child families in both countries, and fertility rates ${ }^{\text {xvi }}$ have remained at 1.2 for over a decade in both countries. In contrast, in the Netherlands there are more families with three children and a higher fertility rate (1.7) during the last decade. However we are not able to test this relationship directly.

In sum, our analysis has resulted in three main contributions to the existing literature. By further investigating the relationship between household composition and partner's characteristics, we obtained insights into the external motivations that influence an entrepreneur to actually undertake entrepreneurship such as partner's employment status (whether they are self-employed or not working), partner's working hours and the presence of small children in the household. In doing so, we further flesh out what we would consider the influence of family context on the 'aspiration vector' proposed by Lee and Venkataraman (2006) which influences the ultimate decision to act on an identified entrepreneurial opportunity. Secondly, our results indicate that not only mothers but also fathers are affected by their partners labor force choices as well as the presence of a child or young children in the household at differing rates in their choice for self-employment. Thirdly, we obtain differing country results for issues such as self-employment as a means to re-enter the labor force, human capital, household income and household finance which indicate the effect of both cultural norms and national policies on the choice of self-employment for both mothers and fathers.

This paper constitutes an initial exploration of the potential influences of partners and children in the family context on the choice to engage in entrepreneurial activity. Our results have indicated some interesting relationships and further research is needed in order to obtain a more comprehensive understanding of these issues. More specifically, additional research could provide insights as to what might be the additional benefits for couples in a family context to both choose self-employment over a combination of selfemployment and formal employment. Also it would be useful to explore the effect of multiple dependent children on a father's choice for self-employment. In addition, further detailed analysis breaking down self-employment activities into specific sectors and categories could increase our insights into the different types of self-employment chosen by mother and fathers in different country contexts. 


\section{References}

Aldrich, H., 1989, 'Networking among women entrepreneurs', in O. Hagen (ed), Women-owned Businesses, New York: Praeger, pp.103 - 132.

Blanchflower, D. and B. Meyer, 1992, 'A longitudinal analysis of the young self-employed in Australia and the United States’, Small Business Economics 6(1), 1 - 20.

Blau, D. and P. Robins, 1989, 'Fertility, Employment and Child Care Costs', Demography 26(2), $287-299$.

Boden, Jr. R, 1999, 'Flexible working hours, family responsibilities, and female self-employment: Gender differences in self-employment selection', American Journal of Economics and Sociology, 58(1) $71-84$.

Bruce, D, 1999, 'Do husbands matter? Married women entering self-employment', Small Business Economics, 13(4) 317 - 329.

Brush, C., 1992, 'Research on Women Business Owners: Past Trends, a New Perspective and Future Directions', Entrepreneurship, Theory and Practice, 16(4) 5-30.

Buttner, E, 1993, 'Female Entrepreneurs: how far have they come?', Business Horizons, MarchApril, 2: 59 - 65.

Caputo, R. and A. Dolinsky, 1998, 'Women's choice to pursue self-employment: the role of financial and human capital members', Journal of Small Business Management, 36(3)8 - 17.

Carter, S. and T. Cannon, 1992, Women as Entrepreneurs, London: Academic Press.

Carter, S. and P. Rosa, 1998, 'The financing of male and female owned business'

Entrepreneurship and Regional Development 10(3) 225 - 241.

Cebrían, I., G. Moreno, M. Samek, R. Semenza and L. Toharia, 2003, 'Nonstandard Work in Italy and Spain: The Quest for Flexibility at the Margin in Two Supposedly Rigid Labor Markets', in: Houseman, S. and M. Osawa (eds.) Nonstandard Work in Developed Economies. Causes and Consequences, Kalamazoo, Michigan: W.E. Upjohn Institute for Employment Research, pp. 89- 129.

Changanti, R, 1986, 'Management in Women-Owned Enterprises', Journal of Small Business Management 24:18-29.

Charboneau, F, 1981, 'The woman entrepreneur’, American Demographics, 3:21 - 23.

Cohen, G, 1996, 'Women Entrepreneurs', Perspectives on Labour and Income, Spring, 23 - 28.

Connelly, R, 1992, 'Self-Employment and Providing Child Care’, Demography 29(1) 17 - 29. 
Cooper, A., F. Gimeno-Gascon, and C. Woo, 1994, 'Initial human and financial capital as predictors of new venture performance’, Journal of Business Venturing, 9: 371 - 395.

Council of Europe, 2002, Recent Demographic Developments in Europe. Council of Europe 2002, Recent Demographic Developments in Europe.

Cuba, R., D. Decenzo and A. Anish, 1983, 'Management practices of successful female business owners’, American Journal of Small Business, 8: 40-45.

Davidsson, P, 1995, 'Culture, Structure and regional levels of entrepreneurship' Entrepreneurship and Regional Development 7(1) $41-62$.

Del Boca, D., M. Locatelli and S. Pasqua, 2000, 'Employment decisions of married women: evidence and explanations’, Labor 14: 35-52.

Del Boca, D, 2002, 'The Effect of Part-time and Childcare on Participation and Fertility of Italian women’, Journal of Population Economics 15: 549-573.

Del Boca, D. and C. Wetzels (eds.), 2007, Social Policies, Labour Markets and Motherhood, Cambridge: Cambridge University Press, forthcoming.

Delmar, F. and P. Davidsson, 2000, 'Where do they come from? Prevalence and characteristics of nascent entrepreneurs’, Entrepreneurship and Regional Development, 12: 1 - 23.

DeMartino, R. and R. Barbato, 2003, 'Differences between women and men MBA entrepreneurs: Exploring family flexibility and wealth creation as career motivators', Journal of Business Venturing, 18(5) $815-832$.

Du Reitz, A. and M. Henrekson, 2000, 'Testing the Female Underperformance Hypothesis', Small Business Economics, 14(1) 1-10.

Eurostat, 1999, European Community Household Panel (ECHP): Selected Indicator for the 1995 Wave, Luxembourg: Office for Official Publications of the European Communities.

Eurostat, 2002, ECHP UDB Description of variables, Data Dictionary, Codebook, and Differences between countries and waves, doc Pan 166/2002-12, Luxembourg: Office for Official Publications of the European Communities.

Fasci, M. and J. Valdez, 1998, 'Performance contrast of male and female-owned small accounting practices’, Journal of Small Business Management, 36(3)1 - 7.

Garcia-Mainar, I. and V.M. Montuenga-Gomez, 2005, 'Education return of wage earners and self-employed workers: Portugal vs. Spain’, Economics of Education Review, 24: 161-170.

Goffee, R. and R. Scase, 1983, 'Business Ownership and Women's Subordination: A Preliminary Study of Female Proprietors’, The Sociological Review, 31: 625-648.

Goffee, R. and R. Scase, 1985, Women in Charge: The Experiences of Female Entrepreneurs, London: George Allen and Unwin. 
Greene, P., M. Hart, E. Gatewood, C. Brush and N. Carter, 2003, 'Women Entrepreneurs: Moving Front to Center: An Overview of Research and Theory’ paper.

Gundry, L. and H. Welsch, 1997, 'The ambitious entrepreneur: Attributes of firms exhibiting high growth strategies’, Frontiers of Entrepreneurship Research 1997, Wellesley, MA: Babson College.

Gustafsson S., C. Wetzels and E. Kenjoh, 2003, 'Employment Choices and Pay Differences between Non-Standard and Standard Work in U.K., Germany, Netherlands and Sweden' in Houseman, S. and Osawa, M. (eds.), Nonstandard Work Arrangements in Japan, Europe, and the United States, Kalamazoo, Michigan: Upjohn Institute for Employment Research, pp. 215-266.

Gustafsson S., C. Wetzels and E. Kenjoh, 2002, 'First Time Mothers' Labor Force Transitions in Britain, Germany, the Netherlands and Sweden', in Mosley, H., J. O’Reilly and K. Schömann (eds.), Labor Markets, Gender and Institutional Change, Essays in Honour of Günther Schmidt, Cheltenham, United Kingdom: Edward Elgar, pp. 185- 211.

Heckman, J., 1974, 'The Estimation of Income and Substitution Effects in a Model of Family Labor Supply’, Econometrica 41(1) 73 - 85.

Hildebrand, V. and D.R. Williams, 2003, 'Self-employment and caring for children: Evidence from Europe’, IRISS working paper no. 2003-06, CEPS/Instead, Luxembourg, http://www.ceps.lu/iriss .

Hisrich, R. and C. Brush, 1987, 'Women entrepreneurs: A longitudinal study', in Frontiers of Entrepreneurship Research 1987, Wellesley, MA: Babson College.

Humphreys, M. and H. McClung, 1981, 'Women entrepreneurs in Oklahoma', Review of Regional Economics and Business, 6:13 - 20.

Johnson, S. and D. Storey, 1993, 'Male and female entrepreneurs and their businesses: A comparative study', in Allen, S. and C. Truman (eds.), Women in business. Perspectives on women entrepreneurs, London: Routledge, pp. 643 - 653.

Justo, R., C. Cruz, J. De Castro, and A. Coduras, 2005, 'Entrepreneur's perception of success: Is there really a gender divide?' Paper presented at RENT IX conference, Naples Italy, November $16-18,2005$.

Kalleberg, A. and K. Leicht, 1991, 'Gender and organizational performance: Determinants of small business survival and success’, The Academy of Management Journal, 34: 136 - 161.

Kaplin, E. 1988, 'Women entrepreneurs: Constructing a framework to examine venture success and business failure', Frontiers of Entrepreneurship Research, Wellesley, MA: Babson College.

Kolvereid, L., S. Shane, and P. Westhead, 1993, 'Is it equally difficult for female entrepreneurs to start businesses in all countries?’, Journal of Small Business Management, 31 (4) 42 - 51.

Lazear, E., 2004, 'Balanced Skills and Entrepreneurship', American Economic Review, 94: 208211. 
Lee, J. and S. Venkataraman, 2006, 'Aspirations, market offerings, and the pursuit of entrepreneurial opportunities’, Journal of Business Venturing, 21(1) 107 - 123.

Lerner, M., C. Brush and R. Hisrich, 1997, 'Israeli women entrepreneurs: an examination of factors affecting performance’, Journal of Business Venturing, 12: 315 - 339.

Locatelli M., Moscato V. and Pasqua S., 2001, 'The European Community Household Panel (ECHP): Elements for Users with Special Focus on Labor and Household Economics’, Working Paper ChilD 24/2001

Longstreth, M., K. Stafford and T. Mauldin, 1998, 'Self-Employed Women and Their Families: Time Use and Socio-Economic Characteristics', Journal of Small Business Management, 25: 30 37.

Marlow, S., 1997, 'Self employed women: New opportunities, old challenges' Entrepreneurship and Regional Development, 9(3) 199 - 210.

Naffziger, D., J. Hornsby and D. Kuratko, 1994, 'A Proposed Research Model of Entrepreneurial Motivation’ Entrepreneurship Theory and Practice 19: 29 - 42.

National Foundation for Women Business Owners (NFWBO), 1996, Research Findings, http://www.nfwbo.org.

Neider, L., 1987, 'A preliminary investigation of female entrepreneurs in Florida', Journal of Small Business Management, 25: 22-29.

Organization for Economic Co-operation and Development (OECD), 2000a, Small Businesses, Job Creation and Growth: Facts, Obstacles and Best Practices, http://www.oecd.org.

Organization for Economic Co-operation and Development (OECD), 2000b, Women Entrepreneurs: Improving Knowledge and Statistics, report, Working Party on Small and Medium-sized Enterprises.

Presser, H. and W. Baldwin, 1980, 'Child Care as a Constraint on Employment: Prevalence, Correlates and Bonding on the Work and Fertility Nexus' American Journal of Sociology 85(5) $1202-1213$.

Presser, H., 1986, 'Shift Work among American Women and Child Care' Journal of Marriage and the Family 48(3) $551-563$.

Reynolds, P., 1997, 'Who starts new firms? - Preliminary explorations of firms-in-gestation', Small Business Economics, 9(4) 449 - 462.

Schwartz, E.B., 1976, 'Entrepreneurship: A New Female Frontier’, Journal of Contemporary Business, 47-76.

Scott, C.E., 1986, 'Why more women are becoming entrepreneurs', Journal of Small Business Management, 24: 37-44.

Shapero, A. 1984, 'The Entrepreneurial Event' in C.A. Kent (ed) Environment for Entrepreneurship. Lexington MA: DC Heath, $21-40$. 
Singh, S., R. Reynolds, and S. Muhammad, 2001, 'A Gender-based performance analysis of micro and small enterprises in Java, Indonesia', Journal of Small Business Management, 39(2), $174-182$.

Smith, N.R., G. McCain and A. Warren, 1982, 'Women Entrepreneurs really are different: A comparison of constructed ideal types of male and female entrepreneurs', Frontiers of Entrepreneurship Research 1982, Wellesley, MA: Babson College, 68-77.

Still, L. and W. Timms, 2000, 'I want to make a difference' Women small business owners: their businesses, dreams, lifestyles and measure of success', Proceedings from the International Conference on Small Business (ICSB), Article 77, http://www.sbaer.uca.edu/Research/2000/ICSB/index.html).

United States Bureau of Census, 2002, http://www.census.gov/ipc/www/idbconf.html.

United States National Center for Health Statistics, 2002, 'Mean Age of Mother, 1970-2000,' National Vital Statistics Reports, 51(1), http://www.cdc.gov/nchs/births.htm

Van Uxem, F.W. and J. Bais, 1996, 'Het starten van een bedrijf: Ervaringen van 2000 Starters', Zoetermeer: EIM.

Welsch, H.B. and E.C. Young, 1982, 'Comparative Analysis of Male and Female Entrepreneurs with Respect to Personality Characteristics', Small Business Problems and Information Source Preferences, Proceedings - International Council for Small Business, 2-10, 1982.

Wetzels, C., 2005, 'Supply and Price of Childcare and Female Labor Force Participation in the Netherlands', Labor 19: 171-210.

Wetzels, C. and K. Tijdens, 2002, Dutch Mothers' Return to Work and The Re-entry Effect on Wage, Cahiers Economiques De Bruxelles, 45(1) 169-189. 
Appendix A.I: Characteristics of parents in paid work (Means and standard deviation in parentheses)

\begin{tabular}{|c|c|c|c|c|c|c|c|}
\hline \multirow[t]{2}{*}{ Variable } & \multirow[t]{2}{*}{ Description } & \multicolumn{2}{|l|}{ Spain } & \multicolumn{2}{|l|}{ Italy } & \multicolumn{2}{|c|}{ Netherlands } \\
\hline & & $\begin{array}{l}\text { Mothers } \\
\mathrm{N}=751\end{array}$ & $\begin{array}{l}\text { Fathers } \\
\mathrm{N}=1,579\end{array}$ & $\begin{array}{l}\text { Mothers } \\
\mathrm{N}=1,132\end{array}$ & $\begin{array}{l}\text { Fathers } \\
\mathrm{N}=2,044\end{array}$ & $\begin{array}{l}\text { Mothers } \\
\mathrm{N}=1,090\end{array}$ & $\begin{array}{l}\text { Fathers } \\
\mathrm{N}=1,327\end{array}$ \\
\hline Self-employed & $\begin{array}{l}\text { Percentage } \\
\text { self-employed }\end{array}$ & .17 & .23 & .18 & .30 & .06 & .09 \\
\hline Age & Respondent's age & $\begin{array}{l}39.78 \\
(7.440)\end{array}$ & $\begin{array}{l}41.22 \\
(7.512)\end{array}$ & $\begin{array}{l}40.95 \\
(7.473)\end{array}$ & $\begin{array}{l}39.23 \\
(8.100)\end{array}$ & $\begin{array}{l}39.91 \\
(6.961)\end{array}$ & $\begin{array}{l}42.04 \\
(6.793)\end{array}$ \\
\hline $\begin{array}{l}\text { Tertiary } \\
\text { education }\end{array}$ & $\begin{array}{l}\text { More than upper } \\
\text { secondary education; } \\
\text { zero otherwise }\end{array}$ & .35 & .24 & .15 & .28 & .21 & .08 \\
\hline $\begin{array}{l}\text { Secondary } \\
\text { education }\end{array}$ & $\begin{array}{l}\text { Upper secondary } \\
\text { education (GCE A } \\
\text { levels, Baccalaureate } \\
\text { or equivalent level), } \\
\text { zero otherwise }\end{array}$ & .18 & .21 & .49 & .21 & .49 & .03 \\
\hline Married & $\begin{array}{l}1=\text { respondent is } \\
\text { married, zero } \\
\text { otherwise }\end{array}$ & .97 & .97 & .98 & .95 & .90 & .93 \\
\hline Grandmother & $\begin{array}{l}1 \text { = grandmother is } \\
\text { present in the } \\
\text { household, zero } \\
\text { otherwise }\end{array}$ & .08 & .08 & .05 & .07 & $*$ & * \\
\hline $\begin{array}{l}\text { Partner - } \\
\text { self-employed }\end{array}$ & $\begin{array}{l}1 \text { = partner is self- } \\
\text { employed, zero } \\
\text { otherwise }\end{array}$ & .22 & .06 & .25 & .04 & .08 & .05 \\
\hline $\begin{array}{l}\text { Partner - } \\
\text { not working }\end{array}$ & $\begin{array}{l}1 \text { = partner is not } \\
\text { working, zero } \\
\text { otherwise }\end{array}$ & .09 & .59 & .12 & .47 & .03 & .29 \\
\hline $\begin{array}{l}\text { Partner - } \\
\text { work hours }\end{array}$ & $\begin{array}{l}\text { Total number of hours } \\
\text { working per week in } \\
\text { main and additional } \\
\text { jobs (also for self- } \\
\text { employed)* }\end{array}$ & $\begin{array}{l}41.18 \\
(16.430)\end{array}$ & $\begin{array}{l}14.83 \\
(29.460)\end{array}$ & $\begin{array}{l}36.80 \\
(16.744)\end{array}$ & $\begin{array}{l}12.44 \\
(23.451)\end{array}$ & $\begin{array}{l}40.28 \\
(12.321)\end{array}$ & $\begin{array}{l}15.02 \\
(13.352)\end{array}$ \\
\hline $\begin{array}{l}\text { Re-entering } \\
\text { work force }\end{array}$ & $\begin{array}{l}1 \text { if unemployed } \\
\text { before current job, } \\
\text { zero otherwise }\end{array}$ & .34 & .31 & .29 & 0.09 & .10 & .13 \\
\hline $\begin{array}{l}\text { Age started } \\
\text { working }\end{array}$ & $\begin{array}{l}\text { Age when the } \\
\text { respondent started } \\
\text { their working life ( } 1^{\text {st }} \\
\text { job or business) }\end{array}$ & $\begin{array}{l}19.92 \\
(7.450)\end{array}$ & $\begin{array}{l}17.00 \\
(4.651)\end{array}$ & $\begin{array}{l}21.58 \\
(8.711)\end{array}$ & $\begin{array}{l}17.41 \\
(5.258)\end{array}$ & $\begin{array}{l}22.02 \\
(9.365)\end{array}$ & $\begin{array}{l}19.17 \\
(6.751)\end{array}$ \\
\hline Part-time work & $\begin{array}{l}1=\text { work } 35 \text { hours } \\
\text { per week or less, zero } \\
\text { otherwise }\end{array}$ & .38 & 0.07 & .36 & .08 & .89 & .09 \\
\hline $\begin{array}{l}\text { Household } \\
\text { finance }\end{array}$ & $\begin{array}{l}\text { Categorical variable } \\
\text { How easy for your hh } \\
\text { to make ends meet? } \\
\text { 1= great difficulty, } \\
2=\text { difficulty; } \\
3=\text { some difficulty; } \\
4=\text { fairly easily; } \\
5=\text { easily; } \\
6 \text { very easily }\end{array}$ & $\begin{array}{l}3.45 \\
(1.18)\end{array}$ & $\begin{array}{l}3.22 \\
(1.200)\end{array}$ & $\begin{array}{l}3.36 \\
(1.33)\end{array}$ & $\begin{array}{l}3.24 \\
(1.252)\end{array}$ & $\begin{array}{l}4.43 \\
(1.002)\end{array}$ & $\begin{array}{l}4.38 \\
(1.031)\end{array}$ \\
\hline
\end{tabular}




\begin{tabular}{|c|c|c|c|c|c|c|c|}
\hline $\begin{array}{l}\text { Household } \\
\text { income }\end{array}$ & $\begin{array}{l}\text { Net household income } \\
\text { from work in } \\
\text { euro/1000 }\end{array}$ & $\begin{array}{l}26.67 \\
(16.970)\end{array}$ & $\begin{array}{l}21.88 \\
(14.803)\end{array}$ & $\begin{array}{l}27.78 \\
(13.482)\end{array}$ & $\begin{array}{l}22.88 \\
(12.852)\end{array}$ & $\begin{array}{l}28.43 \\
(21.916)\end{array}$ & $\begin{array}{l}28.38 \\
(19.172)\end{array}$ \\
\hline $\begin{array}{l}\text { Number of } \\
\text { children }\end{array}$ & $\begin{array}{l}\text { Number of children in } \\
\text { household }\end{array}$ & $\begin{array}{l}1.83 \\
(.783)\end{array}$ & & & & & \\
\hline Age $1^{\text {st }}$ child: & Age of the first child & $\begin{array}{l}14.32 \\
(8.21)\end{array}$ & $\begin{array}{l}14.08 \\
(7.982)\end{array}$ & $\begin{array}{l}15.12 \\
(8.663\end{array}$ & $\begin{array}{l}13.86 \\
(8.243)\end{array}$ & $\begin{array}{l}13.22 \\
(7.05)\end{array}$ & $\begin{array}{l}13.18 \\
(6.892)\end{array}$ \\
\hline $\begin{array}{l}\text { Age } 2^{\text {nd }} \text { child: } \\
* *\end{array}$ & $\begin{array}{l}\text { Age of the second } \\
\text { child }\end{array}$ & $\begin{array}{l}8.03 \\
(9.991)\end{array}$ & $\begin{array}{l}8.104 \\
(8.662)\end{array}$ & $\begin{array}{l}7.36 \\
(9.221)\end{array}$ & $\begin{array}{l}7.284 \\
(8.661)\end{array}$ & $\begin{array}{l}7.56 \\
(7.482)\end{array}$ & $\begin{array}{l}7.91 \\
(7.321)\end{array}$ \\
\hline $\begin{array}{l}\text { Age } 3^{\text {rd }} \text { child: } \\
* *\end{array}$ & Age of the third child & $\begin{array}{l}1.15 \\
(5.661)\end{array}$ & $\begin{array}{l}1.283 \\
(5.741)\end{array}$ & $\begin{array}{l}.507 \\
(4.753)\end{array}$ & $\begin{array}{l}.793 \\
(4.912)\end{array}$ & $\begin{array}{l}.98 \\
(4.720)\end{array}$ & $\begin{array}{l}1.29 \\
(4.922)\end{array}$ \\
\hline
\end{tabular}

* = indicates that it includes a partner who is not working. Means, standard deviation and total number of observations for partner's working hours if the partner is in paid work:

in Spain:

for women: partner's hours per week: $\quad 45.13(10.85)(\mathrm{n}=679)$;

for men: partner's hours per week: $\quad 36.27(12.16)(\mathrm{n}=645)$;

in Italy:

for women: partner's hours per week: $\quad 42.22(9.62)(n=984)$;

for men: partner's hours per week: 33.81 (10.17) $(n=942)$;

in the Netherlands:

for women: partner's hours per week: $41.60 \quad(9.92)(n=975)$;

for men: partner's hours per week: 21.09 (11.04) $(\mathrm{n}=945)$.

** indicates that it includes households not having a second child and not having a third child respectively.

For women having a second child the age of the second child:

In Spain: $\quad 13.25(7.29)(n=476)$;

In Italy: $13.58(7.58)(\mathrm{n}=649)$;

In Netherlands: $11.23(5.92)(\mathrm{n}=763)$;

For men having a second child, the age of the second child:

In Spain: $\quad 13.17(7.05)(\mathrm{n}=272)$;

In Italy: $\quad 12.56(7.13)(\mathrm{n}=1,249)$;

In Netherlands: 11.17 (5.80) (n=972);

For women having a third child, the age of the third child:

In Spain: $\quad 13.40(6.20)(n=112)$

In Italy: $\quad 12.22(6.60)(\mathrm{n}=129)$;

In Netherlands: 10.14 (4.79) $(\mathrm{n}=194)$;

For men having a third child, the age of the third child:

In Spain: $\quad 13.47(6.05)(\mathrm{n}=68)$;

In Italy: $\quad 11.14(6.11)(\mathrm{n}=302)$;

In Netherlands: $\quad 9.66(4.82)(\mathrm{n}=285)$.

ISCED: International Standard Classification of Education (ISCED) designed by UNESCO in 1997 (see also Locatelli et al 2001). The ECHP data categorize education by distinguishing three levels of education. Upper secondary education level (ISCED3); lower than upper secondary (ISCED 0-2) and higher than upper secondary (ISCED 5-7). 
${ }^{\mathrm{i}}$ In this paper, partners are limited to male and female partners.

ii In most cases, in the literature, entrepreneurship is defined as a small or medium-sized business owner.

iii The eleven countries included in the study were: Germany, the Netherlands, Austria, Belgium, France, United Kingdom, Ireland, Italy, Greece, Spain and Portugal.

iv The NLSLME was undertaken to provide a comprehensive understanding of the labor force dynamics of women. The original sample consisted of 5,159 individuals.

${ }^{\mathrm{v}}$ Under-aged children are defined here as those 16 years or younger.

${ }^{v i}$ The aspiration vector of an individual is composed of the combination of economic, social and psychological benefits that an individual would like to have or that she believes she has the means and motivations to achieve for herself (Lee and Venkataraman 2006:108).

vii Defined as the combination of economic, social, and psychological dimensions that are implicitly or explicitly available to the individual from the labor market at a given point in time (Lee and Venkataraman 2006:108).

viii Gainful employment is defined as working with an employer in paid employment.

${ }^{\text {ix }}$ Differences between male and female entrepreneurs are often country-specific suggesting that the differences are derived from the social and political context (Kolvereid et al. 1993).

${ }^{\mathrm{x}}$ For example, while previous earnings predicted the transition to entrepreneurship in both countries, additional education had a positive relationship with self-employment in the US but not in Australia (Blanchflower and Meyer 1992).

${ }^{x i}$ Austria (from 1995), Belgium, Denmark, Finland (from 1996), France, Germany, Greece, Italy, Ireland, Luxembourg, the Netherlands, Portugal, Spain, Sweden (from 1997) and the U.K.

${ }^{x i i}$ For a detailed analysis of the ECHP dataset see Locatelli, Moscato and Pasqua (2001).

xiii We use the variable 'Status in Employment at the time of interview' to define self-employment and gainful employment in our analysis. The variable 'Status in Employment' is available for all persons working more than 1 hour per week, and self-employment and working with an employer in paid employment. Therefore we exclude from our analysis all other status in employment such as working with an employer in paid apprenticeship; working with an employer in training under special related scheme to employment; unpaid work in a family enterprise; and all persons not working for pay such as unemployed, discouraged workers and economically inactive persons.

xiv Time consuming is defined as time spent on children. Using information from the Swedish HUS survey, Gustafsson and Kjulin (1994) show that time costs of children are greater for smaller children aged 1-3 years old than for children 4-7 years old. Both active childcare time and time spent on total household work by parents were greater for the youngest children than for the somewhat older children.

${ }^{x v}$ Typically, in the Netherlands, schooldays are not full time, no school lunch is provided and transport to and from schools has to be organized by the parents. Furthermore there is no facility where the children could be brought when they are ill. With three children in the household, these issues become very difficult to combine with a fulltime job when also taking into account working time schedules and commuting time.

xvi Source: Council of Europe (2002); United States Bureau of Census (2002). 